\title{
Cu adsorption in fixed bed column with three different influent concentration
}

\author{
Huang-Mu Lo ${ }^{1, *}$, Kae-Long Lin ${ }^{2}$, Min-Hsin Liu ${ }^{1}$, Hsung-Ying Chiu ${ }^{1}$, and Fang-Cheng Lo ${ }^{3}$ \\ ${ }^{1}$ Department of Environmental Engineering and Management, Chaoyang University of Technology, 41349 Taichung, Taiwan. \\ ${ }^{2}$ Department of Environmental Engineering, Ilan University, 26047 Ilan, Taiwan. \\ ${ }^{3}$ Graduate Institute of Environmental Engineering, National Taiwan University, 10617 Taipei, Taiwan.
}

\begin{abstract}
Heavy metals from the electroplating wastewater might cause environmental pollution if not well treated. Generally, carbon adsorption might be used for the final step for further trace metals removal. This study investigated the heavy metal $\mathrm{Cu}$ adsorption in the fixed bed column with 1,10 and $100 \mathrm{mg} / \mathrm{L}$ influent concentration. Results showed that $\mathrm{K}_{\mathrm{AB}}$ decreased as influent $\mathrm{Cu}$ concentration increased from 1 to $100 \mathrm{mg} / \mathrm{L}$ while $\mathrm{N}_{0}$ increased as influent concentration increased from 1 to $100 \mathrm{mg} / \mathrm{L}$ as can be found in Adams-Bohart model. $\mathrm{R}^{2}$ was found between 0.8579 and 0.9182 . In Thomas model. $\mathrm{K}_{\mathrm{TH}}$ and $\mathrm{q}_{0}$ showed the similar trend as $\mathrm{K}_{\mathrm{AB}}$ and $\mathrm{N}_{0}$ in the Adams-Bohart model. $\mathrm{K}_{\mathrm{TH}}$ decreased as influent $\mathrm{Cu}$ concentration increased from 1 to $100 \mathrm{mg} / \mathrm{L}$. $\mathrm{q}_{0}$ increased as influent $\mathrm{Cu}$ concentration increased from 1 to $100 \mathrm{mg} / \mathrm{L}$. $\mathrm{R}^{2}$ of regression model was found between 0.9065 and 0.9836 . In Yoon-Nelson model. $\mathrm{K}_{\mathrm{YN}}$ increased as influent $\mathrm{Cu}$ concentration increased from 1 to $100 \mathrm{mg} / \mathrm{L}$ while $\tau$ decreased as influent $\mathrm{Cu}$ concentration increased from 1 to $100 \mathrm{mg} / \mathrm{L}$. Results showed that the three models of Adams-Bohart model, Thmoas model and The Yoon-Nelson model were suitable for the description of $\mathrm{Cu}$ adsorption by activated carbon.
\end{abstract}

\section{Introduction}

Heavy metals such as $\mathrm{Cd}, \mathrm{Cr}, \mathrm{Cu}, \mathrm{Ni}, \mathrm{Pb}$ and $\mathrm{Zn}$ in the wastewater effluent might cause the environmental and health risks if not appropriately treated [1-3]. Wastewater might be treated with physical, chemical and biological processes [4-6] to remove the pollutants such as COD, SS, and heavy metals. Generally, the process for wastewater treatment includes primary sedimentation, active sludge process, secondary sedimentation, coagulation, flocculation, filtration, adsorption and chlorination etc. Among them, adsorption [4] is mostly used as final process to remove the trace organic matters and heavy metals. Organic pollutants and metals adsorption were investigated by batch and fixed bed column to understand the removal of contaminants. Biosorbent was used to examine the adsorption capacity with continuous fixed bed column [7]. Akhigbe et al. (2016) investigated the disinfection and removal performance for Escherichia coli and heavy metals by silver-modified zeolite in a fixed bed column [8]. Coalesced chitosan activated carbon composite for batch and fixed-bed adsorption of cationic and anionic dyes was also represented by Auta and Hameed [9]. Evaluation of the adsorptive capacity by peanut hull pellets for heavy metals in solution was also reported [10]. Adsorption and detection of organic pollutants by fixed bed carbon using nanotube electrochemical membrane was examined by Buffa and Mandler [11]. A review of adsorption of heavy metals on conventional and nanostructured materials for wastewater treatment purposes was intensively reported by Burakov et al. [4]. Biosorption of $\mathrm{Zn}$ (II) from industrial effluents using sugar beet pulp and F. vesiculosus with laboratory and pilot approach was studied by Castro et al. [12]. Chao et al. [13] reported the biosorption of heavy metals on citrus maxima peel, passion fruit shell, and sugarcane bagasse for copper(II), cadmium(II), nickel(II), and lead(II) metal ion removal in a fixed-bed column. Chatterjee et al. [14] reported adsorptive removal of potentially toxic metals (cadmium, copper, nickel and zinc) by chemically treated laterite: Single and multicomponent batch and column study. Ding et al. [15] investigated the removal of lead, copper, cadmium, zinc, and nickel from aqueous solutions by alkali-modified biochar: Batch and column tests. Ghasemabadi et al. [16] presented the continuous adsorption of $\mathrm{Pb}$ (II), $\mathrm{As}$ (III), $\mathrm{Cd}(\mathrm{II})$, and $\mathrm{Cr}(\mathrm{VI})$ using a mixture of magnetic graphite oxide and sand as a medium in a fixed-bed column. Kavand et al. [17] reported the adsorption of heavy metal ions including lead $\left(\mathrm{Pb}^{2+}\right)$, Cadmium $\left(\mathrm{Cd}^{2+}\right)$ and Nickel $\left(\mathrm{Ni}^{2+}\right)$ onto a commercial activated carbon (AC) in single and multi-component aqueous fixed bed column. Different adsorbents for different metals and organic pollutants were investigated as mentioned in the above literature.

This study aims to investigate the breakthrough curve of $\mathrm{Cu}$ adsorption by activated carbon via three different influent concentrations using three models (Adams-

Corresponding author: hmlo@cyut.edu.tw 
Bohart model, Thmoas model and The Yoon-Nelson model).

\section{Materials and methods}

The working fixed bed column was $25 \mathrm{~cm}$ high and the diameter was $2 \mathrm{~cm}$ wide. Thus, the bed volume (BV) was $78.54 \mathrm{~cm}^{3}$. Activated carbon was used as adsorbent. Three influent $\mathrm{Cu}$ concentrations of 1,10 , and $100 \mathrm{mg} / \mathrm{L}$ were used as adsorbate. Influent velocity was $25 \mathrm{~cm} / \mathrm{min}$. The adsorption experiment was conducted in room temperature about $25^{\circ} \mathrm{C}$. Characteristics of activated carbon can be seen in Table 1 .

The filtrate was collected at each BV such as 1, 2, 3 etc. till the effluent $\mathrm{Cu}$ concentrations $\left(\mathrm{C}_{\mathrm{t}}\right)$ was equal to the influent $\mathrm{Cu}$ concentrations $\left(\mathrm{C}_{0}\right)$. Plot the $\mathrm{BV}$ against the $\mathrm{C}_{\mathrm{t}} / \mathrm{C}_{\mathrm{o}}$ ratio, the breakthrough curve can be obtained.

Three dynamic adsorption models were used to describe the adsorption behaviour of $\mathrm{Cu}$ adsorption on activate carbon. Three dynamic adsorption models $(8,16)$ were expressed as following three equations:

Adams-Bohart model:

$$
\ln \left(\mathrm{C}_{\mathrm{t}} / \mathrm{C}_{0}\right)=\mathrm{K}_{\mathrm{AB}} \mathrm{C}_{0} \mathrm{t}-\mathrm{K}_{\mathrm{AB}} \mathrm{N}_{0}(\mathrm{Z} / \mathrm{F})
$$

where $\mathrm{K}_{\mathrm{AB}}=$ adsorbed dynamic constant (L/mg-min) $\mathrm{C}_{\mathrm{t}} / \mathrm{C}_{0}=$ Effluent concentration/Influent concentration $\mathrm{N}_{0}=$ Saturated concentration $(\mathrm{mg} / \mathrm{L})$

$\mathrm{Z}=$ Height of fixed bed column $(\mathrm{cm})$

$\mathrm{F}=$ Flow velocity of adsorbate $(\mathrm{cm} / \mathrm{min})$

Thomas model:

$$
\ln \left(\left(\mathrm{C}_{0} / \mathrm{C}_{\mathrm{t}}\right)-1\right)=\mathrm{K}_{\mathrm{TH}} \mathrm{q}_{0} \mathrm{~W} / \mathrm{Q}-\mathrm{K}_{\mathrm{TH}} \mathrm{C}_{0} \mathrm{t}
$$

where $\mathrm{K}_{\mathrm{TH}}=$ adsorbed dynamic constant (L/mg-min) $\mathrm{C}_{0} / \mathrm{C}_{\mathrm{t}}=$ Influent concentration/Effluent concentration $\mathrm{W}=$ weight of adsorbent $(\mathrm{g})$

$\mathrm{q}_{0}=$ adsorbate adsorbed by adsorbent $(\mathrm{mg} / \mathrm{g})$

$\mathrm{Q}=$ Influent flow rate $(\mathrm{L} / \mathrm{min})$

$$
\ln \left(C_{t} /\left(C_{0}-C_{t}\right)\right)=K_{Y N} t-\tau K_{Y N}
$$

where $\mathrm{K}_{\mathrm{YN}}=$ adsorbed dynamic constant ( $\left.1 / \mathrm{min}\right)$ $\tau=$ time as $50 \%$ adsorbate $\mathrm{Cu}$ adsorbed on activated carbon $(\mathrm{t})$

Table 1. Characteristics of activated carbon.

\begin{tabular}{ll}
\hline Parameters & \\
\hline Particle size & $3 \sim 4 \mathrm{~mm}^{3}$ \\
Ball-pan Hardness & $\geqq 95 \%$ \\
Moisture as packed & $\geqq 8 \%$ \\
Ash & $\geqq 5 \%$ \\
Iodine Number & $\geqq 1050 \mathrm{mg} / \mathrm{g}$ \\
Total Surface Area(BET, $\left.\mathrm{N}_{2}\right)$ & $\geqq 1100 \mathrm{~m}^{2} / \mathrm{g}$ \\
Bulk density & $0.4 \sim 0.55 \mathrm{~g} / \mathrm{cc}$ \\
pH of Water Extract & $7-11$ \\
\hline
\end{tabular}

Using equation $(1) \sim(3)$, plot the $\mathrm{Y}$ axis against the $\mathrm{X}$ axis $(\mathrm{BV})$, the regression lines were obtained. The parameters in the equations can be obtained as shown in Table 2-4.

\section{Results and discussion}

Parameters of three models can be found in Table 2-4.

Table 2. Adams-Bohart model-Cu.

\begin{tabular}{llllll}
\hline $\begin{array}{l}\text { Influent } \\
\begin{array}{l}\text { conc. } \\
(\mathrm{mg} / \mathrm{L})\end{array}\end{array}$ & $\begin{array}{l}\text { Bed height Velocity } \\
(\mathrm{mm})\end{array}$ & $\begin{array}{l}\mathrm{K}_{\mathrm{AB}} \\
(\mathrm{mL} / \mathrm{min})\end{array}$ & $\begin{array}{l}\mathrm{N}_{0} \\
(\mathrm{mg} / \mathrm{m})\end{array}$ & $\mathrm{R}^{2}$ \\
\hline 1 & 250 & 25 & 0.0296 & 76.85 & 0.8579 \\
10 & 250 & 25 & 0.0070 & 292.84 & 0.8744 \\
100 & 250 & 25 & 0.0003 & 2715.92 & 0.9182 \\
\hline
\end{tabular}

Table 2 showed the parameters of Adams-Bohart model. $\mathrm{K}_{\mathrm{AB}}$ decreased from 0.0296 to $0.003 \mathrm{~L} / \mathrm{mg}-\mathrm{min}$ as influent concentration increased from 1 to $100 \mathrm{mg} / \mathrm{L}$ while $\mathrm{N}_{0}$ increased from 76.85 to $2715.92 \mathrm{mg} / \mathrm{L}$ as influent $\mathrm{Cu}$ concentration increased from 1 to $100 \mathrm{mg} / \mathrm{L}$. $\mathrm{R}^{2}$ was found between 0.8579 and 0.9182 .

Table 3. Thomas model-Cu.

\begin{tabular}{llllll}
\hline $\begin{array}{l}\text { Influent } \\
\text { conc. } \\
(\mathrm{mg} / \mathrm{L})\end{array}$ & $\begin{array}{l}\text { Bed height Velocity } \\
(\mathrm{mm})\end{array}$ & $\begin{array}{l}\mathrm{K}_{\mathrm{TH}} \\
(\mathrm{mL} / \mathrm{min})\end{array}(\mathrm{L} / \mathrm{min}-\mathrm{mg})$ & $\begin{array}{l}\mathrm{q}_{0} \\
(\mathrm{mg} / \mathrm{g})\end{array}$ & $\mathrm{R}^{2}$ \\
\hline 1 & 250 & 25 & 0.0442 & 92.46 & 0.9065 \\
10 & 250 & 25 & 0.0190 & 271.34 & 0.9836 \\
100 & 250 & 25 & 0.0019 & 1432.41 & 0.9361 \\
\hline
\end{tabular}

Table 3 showed the parameters of Thomas model. $\mathrm{K}_{\mathrm{TH}}$ and $\mathrm{q}_{0}$ showed the similar trend as $\mathrm{K}_{\mathrm{AB}}$ and $\mathrm{N}_{0}$ in the Adams-Bohart model. $\mathrm{K}_{\mathrm{TH}}$ decreased from 0.0442 to $0.0019 \mathrm{~L} / \mathrm{min}-\mathrm{mg}$ as influent $\mathrm{Cu}$ concentration increased from 1 to $100 \mathrm{mg} / \mathrm{L} . \mathrm{q}_{0}$ increased from 92.46 to 1432.41 $\mathrm{mg} / \mathrm{g}$ as influent $\mathrm{Cu}$ concentration increased from 1 to $100 \mathrm{mg} / \mathrm{L} . \mathrm{R}^{2}$ of regression model was found between

\begin{tabular}{|c|c|c|c|c|c|}
\hline $\begin{array}{l}\text { Influent } \\
\text { conc. } \\
\text { (mg/L) }\end{array}$ & $\begin{array}{l}\text { Bed height } \\
(\mathrm{mm})\end{array}$ & $\begin{array}{l}\text { Velocity } \\
(\mathrm{mL} / \mathrm{min})\end{array}$ & $\begin{array}{l}\mathrm{K}_{\mathrm{YN}} \\
(1 / \mathrm{min})\end{array}$ & $\begin{array}{l}\tau \\
(\min )\end{array}$ & $\mathrm{R}^{2}$ \\
\hline 1 & 250 & 25 & 0.043 & 53.23 & 0.9065 \\
\hline 10 & 250 & 25 & 0.1898 & 15.25 & 50.9836 \\
\hline 100 & 250 & 25 & 0.1889 & 8.05 & 0.9361 \\
\hline
\end{tabular}
0.9065 and 0.9836 .

Table 4. The Yoon-Nelson model-Cu.

Table 4 showed the parameters of the Yoon-Nelson model. $\mathrm{K}_{\mathrm{YN}}$ increased as influent $\mathrm{Cu}$ concentration increased while $\tau$ decreased as influent $\mathrm{Cu}$ concentration increased. $\mathrm{K}_{\mathrm{YN}}$ increased from 0.043 to $0.18891 / \mathrm{min}$ as influent $\mathrm{Cu}$ concentration increased from 1 to $100 \mathrm{mg} / \mathrm{L}$ while $\tau$ decreased from 53.23 to $8.05 \mathrm{~min}$ as influent $\mathrm{Cu}$ concentration increased from 1 to $100 \mathrm{mg} / \mathrm{L}$. The $\tau(53.23 \mathrm{~min})$ needed to be half saturated in the influent $\mathrm{Cu}$ concentration of $1 \mathrm{mg} / \mathrm{L}$ was $\sim 3.5$ times that of $10 \mathrm{mg} / \mathrm{L}$ influent $\mathrm{Cu}$ concentration and $\sim 7$ times that of $100 \mathrm{mg} / \mathrm{L}$ influent $\mathrm{Cu}$ concentration. 
The breakthrough curves of 1,10 and $100 \mathrm{mg} / \mathrm{L} \mathrm{Cu}$ influent concentration and the regression of the Adams-Bohart model, Thomas model and The Yoon-Nelson model was shown in Figure 1-3.

Figure 1 showed the influent $\mathrm{Cu} 1 \mathrm{mg} / \mathrm{L}$ adsorption breakthrough curve and the three dynamic adsorption model and regression line. Results was presented in Table 2-4.
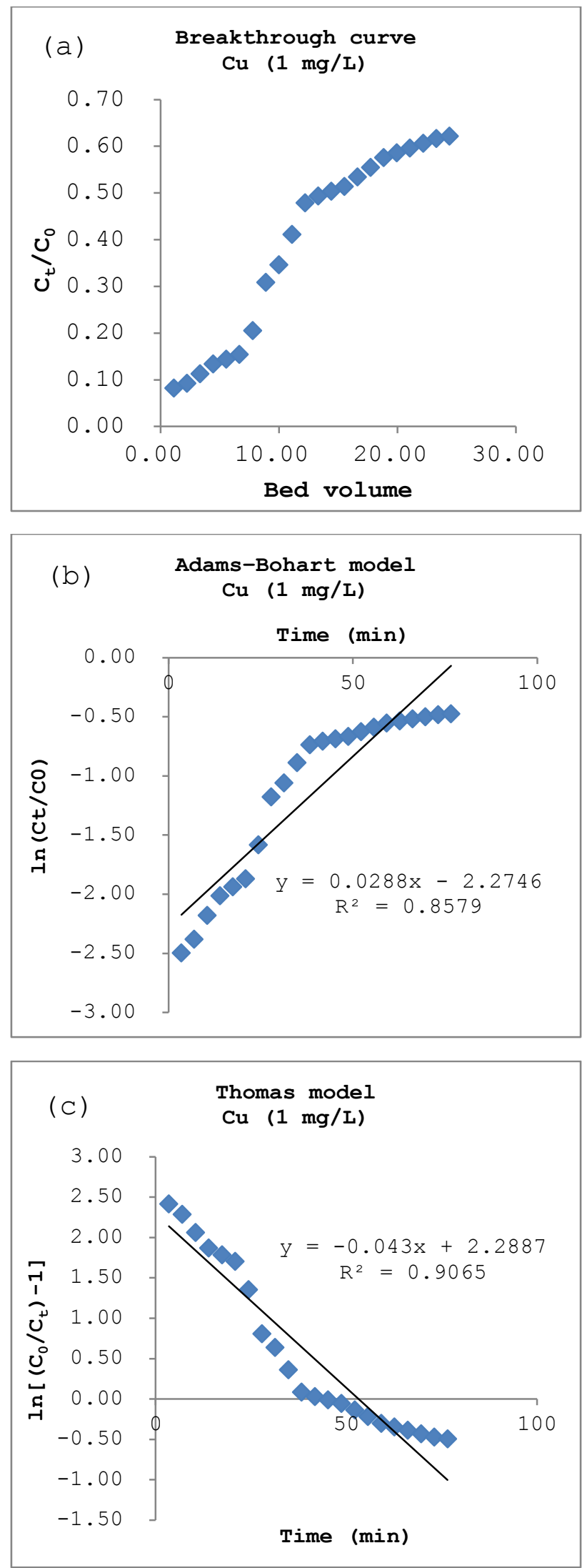

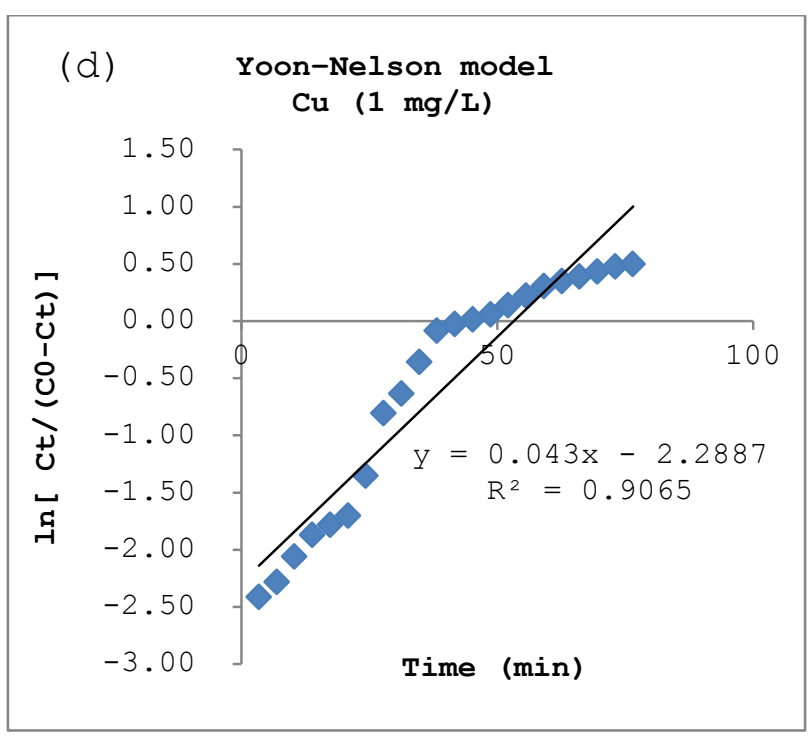

Fig. 1. $\mathrm{Cu}$ adsorption breakthrough curve and three dynamic adsorption model in fixed bed column $(\mathrm{Cu}: \sim 1 \mathrm{mg} / \mathrm{L}$, column height: $25 \mathrm{~cm}$, flowing velocity: $25 \mathrm{~cm} / \mathrm{min}$ )

Figure 2 showed the influent $\mathrm{Cu} 10 \mathrm{mg} / \mathrm{L}$ adsorption breakthrough curve and the three dynamic adsorption model and regression line. Results was presented in Table 2-4.
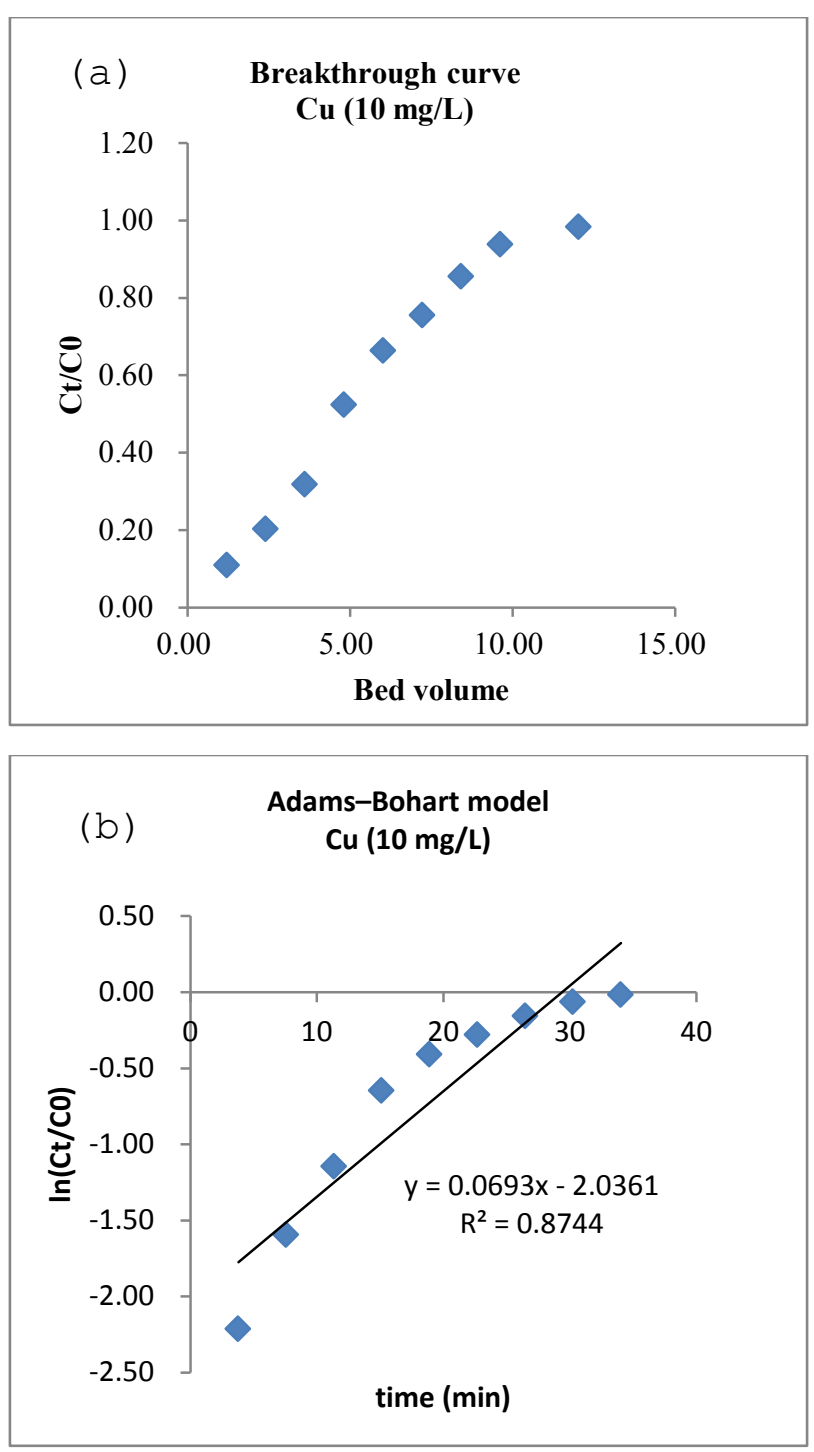

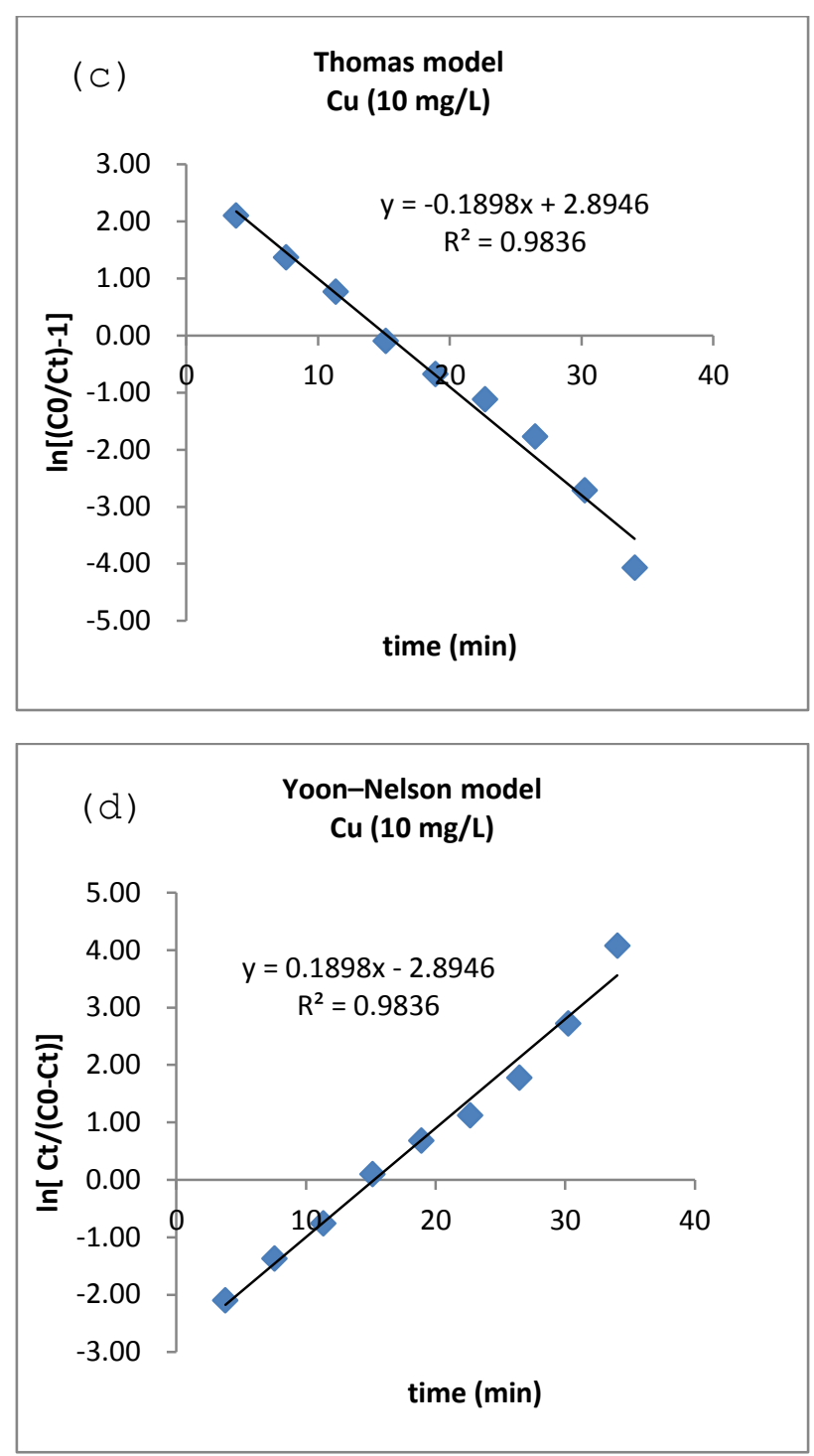

Fig. 2. $\mathrm{Cu}$ adsorption breakthrough curve and three dynamic adsorption model in fixed bed column $(\mathrm{Cu}: \sim 10 \mathrm{mg} / \mathrm{L}$, column height: $25 \mathrm{~cm}$, flowing velocity: $25 \mathrm{~cm} / \mathrm{min}$ )

Figure 3 showed the influent $\mathrm{Cu} 100 \mathrm{mg} / \mathrm{L}$ adsorption breakthrough curve and the three dynamic adsorption model and regression line. Results was presented in Table 2-4.

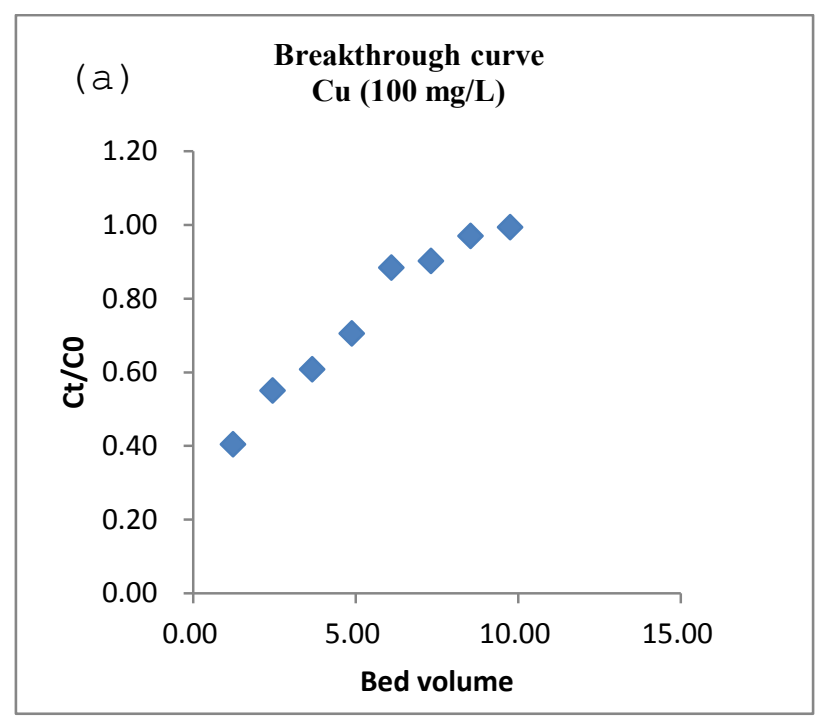

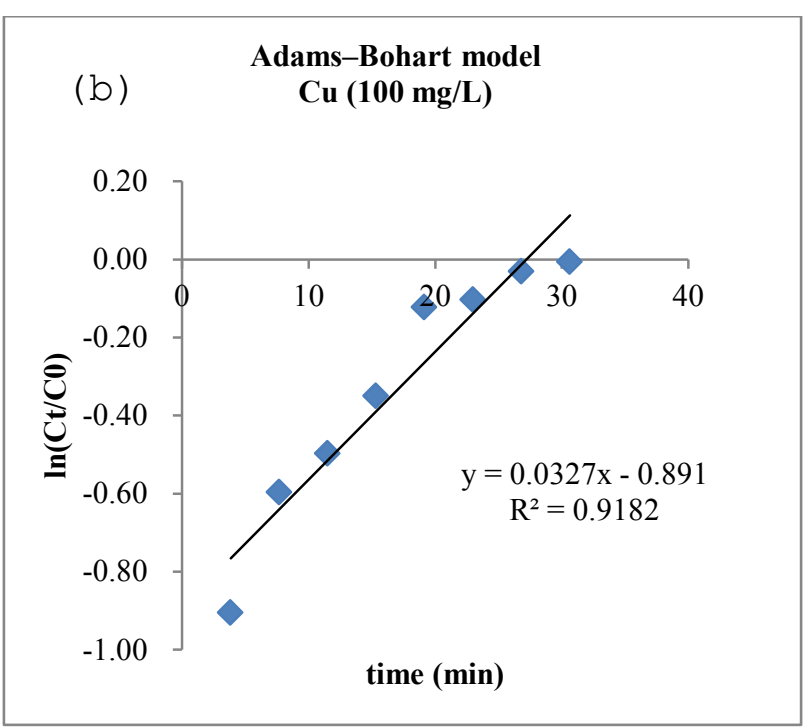
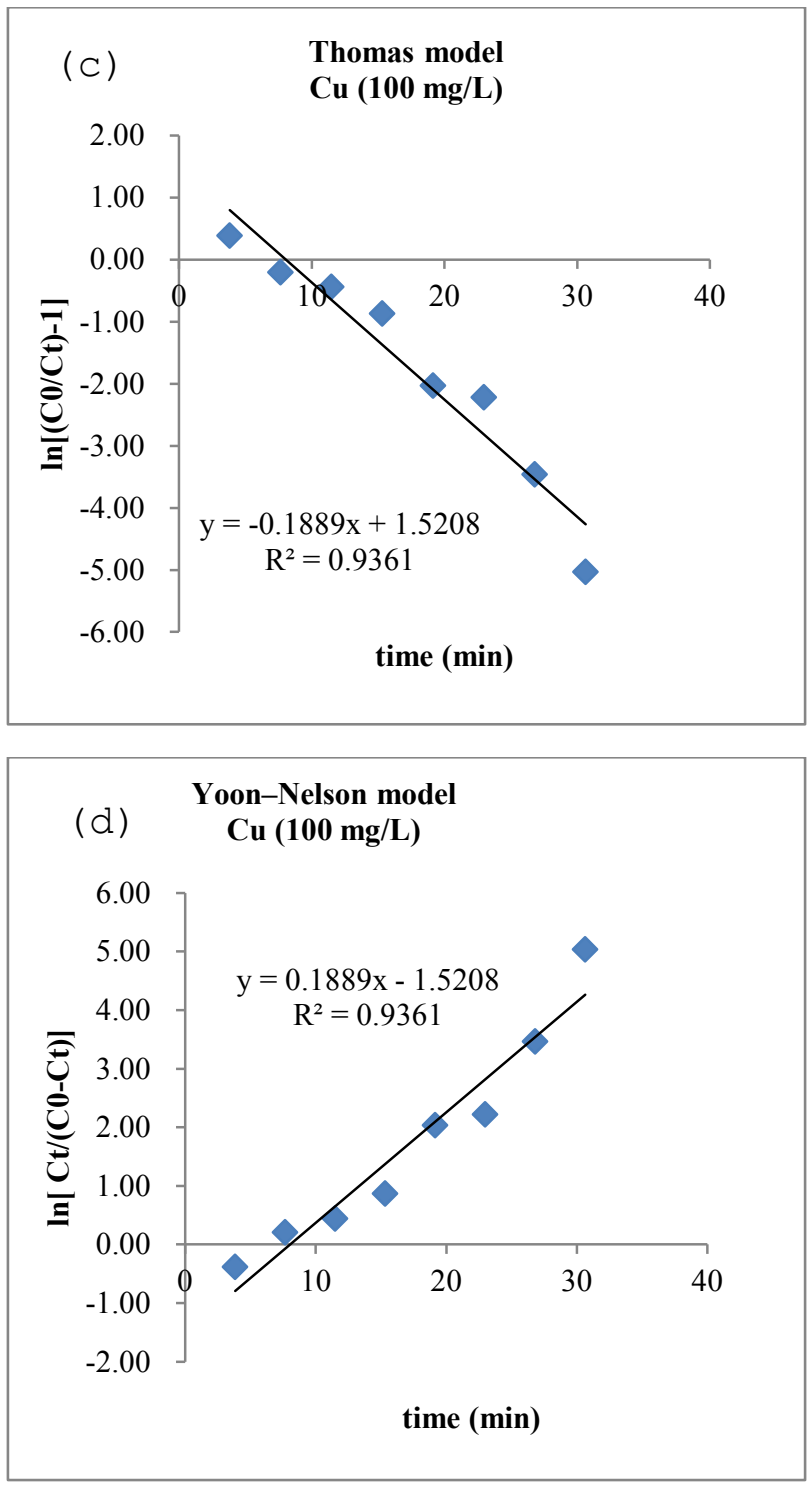

Fig. 3. $\mathrm{Cu}$ adsorption breakthrough curve and three dynamic adsorption model in fixed bed column $(\mathrm{Cu}: \sim 100 \mathrm{mg} / \mathrm{L}$, column height: $25 \mathrm{~cm}$, flowing velocity: $25 \mathrm{~cm} / \mathrm{min}$ ) 
Results showed that $\mathrm{Cu}$ adsorption in fixed bed column were described well in the Adams-Bohart model, Thmoas model and The Yoon-Nelson model.

\section{Conclusions}

Activated carbon was used to adsorb the influent $\mathrm{Cu}$ concentration of 1,10 and $100 \mathrm{mg} / \mathrm{L}$ in fixed bed column. Results showed that breakthrough curve was found quick to reach saturation point in influent $\mathrm{Cu} 100 \mathrm{mg} / \mathrm{L}$ concentration than in influent $\mathrm{Cu} 1$ and $10 \mathrm{mg} / \mathrm{L}$ concentration. Results also showed that the three models of Adams-Bohart model, Thmoas model and The Yoon-Nelson model were suitable for the description of $\mathrm{Cu}$ adsorption.

\section{References}

1. B. Hu, S. Shao, Z. Fu, Y. Li, H. Ni, S. Chen, Y. Zhou, B. Jin, Z. Shi, Sci. Total Environ. 658, 614-625 (2019)

2. Q. Yang, Z. Li, X. Lu, Q. Duan, L. Huang, and J. Bi, Sci. Total Environ. 642, 690-700 (2018)

3. L. Zhang, G. Zhu, X. Ge, G. Xu, and Y. Guan, J. Hazard. Mater. 360, 32-42 (2018)

4. A.E. Burakov, E.V. Galunin, I.V. Burakova, A.E. Kucherova, S. Agarwal, A.G. Tkachev, V.K. Gupta, Ecotoxicol. Environ. Saf. 148, 702-712 ( 2018)

5. D. Wang, G. Tang, Z. Yang, X. Li, G. Chai, T. Liu, X. Cao, B. Pan, J. Li, G. Sheng, X. Zheng, Z. Ren, J. Hazard. Mater. (2019), https://doi.org/10.1016/j.jhazmat.2019.03.069
6. L. Wang, Y. Wang, F. Ma, V. Tankpa, S. Bai, X. Guo, X. Wang, Sci. Total Environ. 668, 1298-1309 (2019)

7. A. Abdolali, H.H. Ngo, W. Guo, J.I. Zhou, J. Zhang, S. Liang, S.W. Chang, D.D. Nguyen, Y. Liu, Bioresour. Technol. 229, 78-87 (2017)

8. L. Akhigbe, S. Ouki, and D. Saroj, Chem. Eng. J. 295, 9298, (2016)

9. M. Auta and B. H. Hameed, Colloids Surf B Biointerfaces 105, 199-206, (2013)

10. P. Brown, I. Atly Jefcoat, D. Parrish, S. Gill, and E. Graham, Adv. Environ. Res. 4, 19-29 (2000)

11. A. Buffa and D. Mandler, Chem. Eng. J. 359, 130-137 (2019)

12. L. Castro, M. L. Blázquez, F. González, J. A. Muñoz, and A. Ballester, Sci. Total Environ. 598, 856-866 (2017)

13.H.-P. Chao, C.-C. Chang, and A. Nieva, J. Ind. Eng. Chem. . 20, 3408-3414, (2014)

14. S. Chatterjee, I. Sivareddy, and S. De, J. Environ. Chem. Eng. 5, 3273-3289 (2017)

15. Z. Ding, X. Hu, Y. Wan, S. Wang, and B. Gao, J. Ind. Eng. Chem. 33, 239-245 (2016)

16. S. M. Ghasemabadi, M. Baghdadi, E. Safari, and F. Ghazban, J. Environ. Chem. Eng. 6, 4840-4849 (2018)

17. M. Kavand, E. Fakoor, S. Mahzoon, and M. Soleimani, Process Saf. Environ. Prot. 113, 330-342 (2018) 